\title{
IMPLEMENTASI FACE MASK DETECTION UNTUK MENGHAMBAT LAJU PENYEBARAN COVID-19 BERBASIS MACHINE LEARNING
}

\author{
Reza Marwansyah ${ }^{1}$, Astriana Mulyani ${ }^{2}$ \\ Program Studi Teknik Informatika ${ }^{1}$, Program Studi Teknik Informatika ${ }^{2}$ \\ Universitas Nusa Mandiri ${ }^{1}$, Universitas Nusa Mandiri ${ }^{2}$ \\ rezakatsuhiko@gmail.com¹ ${ }^{1}$ astriana.atm@nusamandiri.ac.id ${ }^{2}$
}

\begin{abstract}
Abstrak: Terus meningkatnya kasus Coronavirus Disease-2019 (COVID-19) di Indonesia disebabkan karena masyarakat selama ini tidak disiplin dalam menerapkan protokol kesehatan khususnya dalam penggunaan masker. Dalam hal ini, upaya pemerintah Indonesia untuk menghambat laju penyebaran COVID-19 yaitu dengan melakukan razia masker. Kurangnya personel dalam menjalankan operasi razia masker menjadi kendala yang harus dihadapi. Agar penerapan disiplin dalam menggunakan masker berjalan dengan baik, maka dibuatlah Face Mask Detection. Face Mask Detection ini berbasis Machine Learning dengan algoritma Convolutional Neural Network (CNN) berarsitektur MobileNetV2. MobileNetV2 mampu mengefisiensi penggunaan computing resource yang tinggi dibandingkan dengan arsitektur CNN lainnya. Hasil training tersebut menghasilkan model dengan nilai accuracy $93 \%$. Hasil dari penelitian ini adalah sistem yang mampu mendeteksi apakah orang tersebut menggunakan masker atau tidak.
\end{abstract}

Kata kunci: COVID-19, Haar Cascade Classifier, Machine Learning, Masker, MobileNetV2

\begin{abstract}
The continued increase in cases of Coronavirus Disease-2019 (COVID-19) in Indonesia is since that community has undisciplined in implementing health protocols, especially in the use of masks. In this case, the Indonesian government's efforts to inhibit the spread of COVID-19 are by carrying out mask raids. The lack of personnel in carrying out mask raids is an obstacle that must be faced. For the application of discipline in using masks to run well, Face Mask Detection was made. The Face Mask Detection is based on Machine Learning with the Convolutional Neural Network (CNN) algorithm with the MobileNetV2 architecture. MobileNetV2 is capable of efficient computing resource usage compared to other CNN architectures. The training results resulted in a model with an accuracy value of 93\%. The result of this study is a system that can detect whether the person is wearing a mask or not.
\end{abstract}

Keywords: COVID-19, Haar Cascade Classifier, Machine Learning, Masker, MobileNetV2

\section{PENDAhUluan}

Ancaman virus Corona atau Servere acute Respiratory Coronavirus 2 (SARS-CoV-2) kini telah menyebar ke sejumlah negara termasuk Indonesia. Penyakit Coronavirus Disease-2019 (COVID-19) telah menjadi pandemi di Indonesia sebagai bencana non alamiah berupa wabah penyakit yang harus dilakukan penanggulangannya. Badan Kesehatan Dunia PBB, WHO (World Health Organization) mendeklarasikan keadaan darurat internasional terkait virus mematikan Corona [1]. WHO pun memberikan panduan untuk mecegah penularan virus yaitu dengan cara menjaga kebersihan, menjaga interaksi sosial (physical distancing), memakai masker dan melakukan lockdown wilayah atau karantina wilayah.

DOI: 10.52362/jisamar.v5i2.399

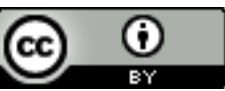

Ciptaan disebarluaskan di bawah Lisensi Creative Commons Atribusi 4.0 Internasional. 


\section{Journal of Information System, Applied, Management, Accounting and Research. http://journal.stmikjayakarta.ac.id/index.php/jisamar, jisamar@stmikjayakarta.ac.id, jisamar2017@gmail.com \\ e-ISSN: 2598-8719 (Online), p-ISSN: 2598-8700 (Printed), Vol. 5 No.2 Mei 2021}

Dalam penerapannya, masyarakat masih belum semua menerapkan himbauan tersebut. Hal ini terlihat ketika masih banyak masyarakat ekonomi kelas menengah bawah yang masih beraktifitas diluar rumah. Mereka beralasan karena harus mencari nafkah seperti pedagang kaki lima, ojek online maupun masyarakat yang mengandalkan upah harian. Jika hal ini masih terjadi, potensi penularan virus pun tidak dapat dicegah penyebarannya. Presiden Republik Indonesia Joko Widodo mengeluarkan kebijakan melalui himbauan yang dikeluarkan oleh WHO, untuk melakukan upaya mencegah penyebaran virus [2], salah satunya adalah penggunaan masker. Dalam penerapannya, masyarakat masih belum semua menerapkan himbauan tersebut. Jika hal ini masih terjadi, potensi penularan virus pun tidak dapat dicegah penyebarannya.

Selama ini, salah satu cara untuk mendeteksi masker yang dilakukan oleh pihak pemerintah dengan melakukan razia masker di berbagai lokasi untuk menekan penyebaran COVID-19. Misalnya, guna menekan angka penyebaran COVID-19 di DKI Jakarta, Satuan Polisi Pamong Praja (Satpol PP) menggelar operasi tertib masker [3]. Dalam pelaksanaanya, kurangnya personel [4] dalam menjalankan operasi razia masker menjadi kendala yang dialami. Hal ini menyebabkan razia masker menjadi tidak maksimal seperti yang diharapkan. Penelitian ini bertujuan untuk meningkatkan keefektifitas dalam memantau warga yang tidak menggunakan masker dibandingkan dengan razia masker oleh pihak pemerintah.

\subsection{Identifikasi Masalah}

Berdasarkan latar belakang masalah yang telah dijelaskan, dapat diidentifikasikan sebagai berikut :

1. Bagaimana permasalahan penggunaan masker khusus nya di area RW. 06 Kelurahan Utan Panjang, Kecamatan Kemayoran, Jakarta Pusat?

2. Bagaimana cara kerja Face Mask Detection di area RW. 06 Kelurahan Utan Panjang, Kecamatan Kemayoran, Jakarta Pusat dengan menggunakan Machine Learning?

\subsection{Tujuan Penelitian}

Tujuan dari penelitian ini adalah :

1. Membuat Face Mask Detection untuk mempermudah memantau warga yang tidak memakai masker.

2. Face Mask Detection meningkatkan keefektifitas dalam memantau warga yang tidak menggunakan masker dibandingkan dengan razia masker oleh pihak pemerintah.

3. Untuk implementasi di camera device seperti CCTV khususnya di area RW. 06 Kelurahan Utan Panjang Kecamatan Kemayoran Jakarta Pusat.

\subsection{Ruang Lingkup}

Untuk lebih memfokuskan pembahasan, yang menjadi batasan masalah dalam penelitian ini, antara lain :

1. Sistem yang dibangun berbasis Terminal (Command Line Interface/CLI) pada Sistem Operasi Linux Ubuntu.

2. Menggunakan 2 (dua) dataset yaitu dataset wajah yang memakai masker dan dataset wajah yang tidak memakai masker.

3. Face Mask Detection dilakukan dengan menggunakan bahasa pemograman Python versi 3.0 keatas.

4. Model Machine Learning yang diimplementasikan dalam sistem Face Mask Detection menggunakan salah satu arsitektur Convolutional Neural Network (CNN) yaitu MobileNetV2.

5. Objek yang dideteksi hanya wajah yang menggunakan masker dan tanpa menggunakan masker.

\section{METODE DAN MATERI}

\subsection{Teknik Pengumpulan Data}

1. Data Primer

Data yang digunakan adalah data gambar wajah di area RW. 06 Kelurahan Utan Panjang Kecamatan Kemayoran Jakarta Pusat dengan menggunakan beberapa camera device. Data wajah yang didapatkan

DOI: 10.52362/jisamar.v5i2.399

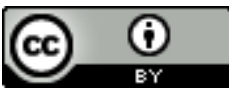

Ciptaan disebarluaskan di bawah Lisensi Creative Commons Atribusi 4.0 Internasional. 


\section{Journal of Information System, Applied, Management, Accounting and Research. http://journal.stmikjayakarta.ac.id/index.php/jisamar, jisamar@stmikjayakarta.ac.id , jisamar2017@gmail.com \\ e-ISSN: 2598-8719 (Online), p-ISSN: 2598-8700 (Printed), Vol. 5 No.2 Mei 2021}

menggunakan format JPEG yang nantinya akan diolah menggunakan Machine Learning untuk mendeteksi apakah warga RW. 06 tersebut menggunakan masker atau tidak.

\section{Data Sekunder}

Data sekunder yang diperlukan adalah Masked Face Recognition Dataset [5]. Dataset ini adalah gabungan dari Masked Face Detection Dataset (MFDD), Real-world Masked Face Recognition (RMFRD) dan Simulated Masked Face Recognition Dataset (SMFRD). Dataset ini telah diuji dalam penelitian sebelumnya dimana mencapai akurasi pengenalan sebesar 95\%. Dataset tersebut menjadi 2 label, antara lain Masker sebanyak 1916 gambar dan Tanpa Masker sebanyak 1930 gambar. Berikut ini kumpulan dataset tersebut pada Gambar 1.
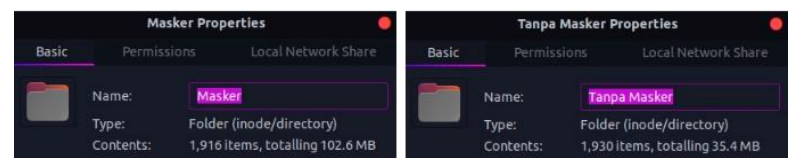

Gambar 1. Banyaknya Dataset Masker dan Dataset Tanpa Masker

\subsection{Proses Pembuatan Model}

\section{Data Preparation}

Pada tahapan ini, akan dilakukan pengolahan data menggunakan data yang telah dikumpulkan. Data yang dimaksud adalah Masked Face Recognition Dataset yang didapatkan oleh peneliti berdasarkan penelitian sebelumnya yang dilakukan oleh Zhongyuan Wang dan rekan-rekan.

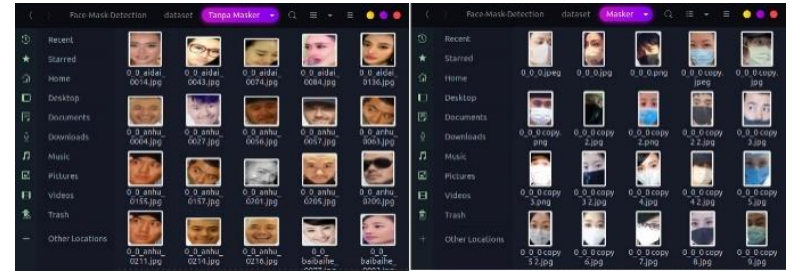

Gambar 2. Banyaknya Dataset Masker dan Dataset Tanpa Masker

\section{Data Preprocessing}

Data preprocessing merupakan beberapa proses persiapan data sebelum dilakukan proses training untuk pembuatan model Machine Learning.

\section{1) Data Selection}

Proses ini dilakukan untuk menganilisis data-data yang relevan karena sering ditemukan bahwa tidak semua data dibutuhkan dalam proses Machine Learning. Dari semua data yang digunakan hanya gambar wajah memakai masker dengan label Masker dan gambar wajah tidak memakai masker dengan label Tanpa Masker.

\section{2) Data Cleaning}

Hal ini dilakukan agar tidak ada duplikasi data sehingga data tersebut dapat diolah dan dilakukan proses pembuatan model Machine Learning.

\section{3) Face Cropping}

Pembagian pada bagian wajah ini terdiri dari 2 (dua) label yaitu bagian wajah yang memakai masker dan bagian wajah yang tidak memakai masker. Hal ini bertujuan agar saat proses pengolahan dataset menjadi model Machine Learning hanya bagian wajah saja yang kan dilakukan proses training sehingga bagian selain wajah tidak perlu dilakukan pencocokan. Proses face cropping ini menggunakan algoritma Haar Cascade sebagai pendeteksi wajahnya.

DOI: 10.52362/jisamar.v5i2.399

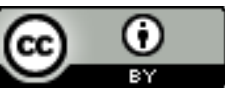

Ciptaan disebarluaskan di bawah Lisensi Creative Commons Atribusi 4.0 Internasional. 


\section{Journal of Information System, Applied, Management, Accounting and Research.}

http://journal.stmikjayakarta.ac.id/index.php/jisamar, jisamar@stmikjayakarta.ac.id, jisamar2017@gmail.com

e-ISSN: 2598-8719 (Online), p-ISSN: 2598-8700 (Printed), Vol. 5 No.2 Mei 2021
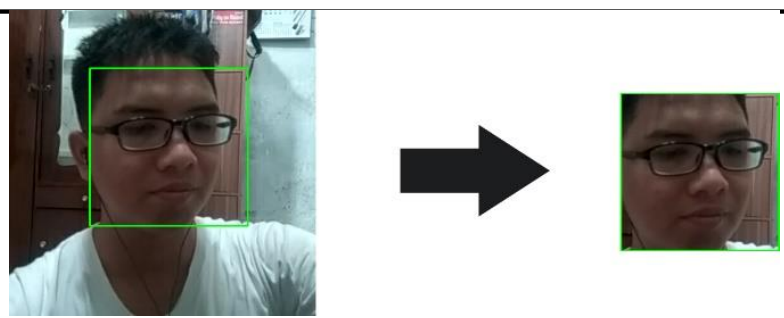

Gambar 3. Face cropping menggunakan algoritma Haar Cascade pada dataset Tanpa Masker

4) Resize Ukuran Image pada Dataset

Pada tahap ini akan dilakukan pengolahan dataset dengan cara mengecilkan atau mengatur image size dari dataset yang telah dikumpulkan. Hal ini bertujuan agar saat penginputan dan proses classification pada arsitektur MobileNetV2 menjadi seragam dan mengatasi loss accuracy atau kehilangan tingkat akurasi pada proses training. Pada proses ini image akan di resize menajadi ukuran 224 x 224 pixel.

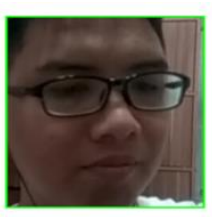

$(250 \times 248)$

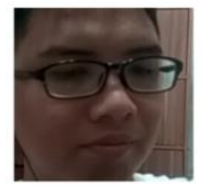

$(224 \times 224)$

Gambar 4. Resize image size pada dataset

3. Requirement Python Packages

Didalam penelitian ini, packages Machine Learning yang dibutuhkan sebagai berikut :

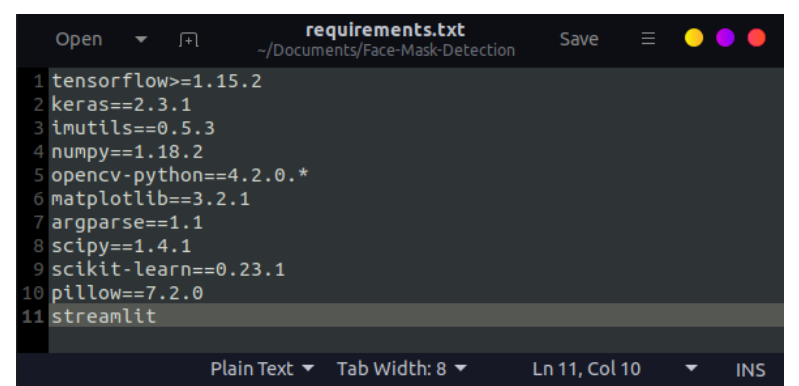

Gambar 5. List Requirement Python Package

\section{Validation Machine Learning Model}

Untuk membuat sebuah model Machine Learning yang merupakan model terbaik yang akan memberikan hasil maksimal dan akurat, perlu dilakukan validasi terhadap model sebelum memasuki proses training. Pada penelitian ini, validasi model yang digunakan adalah Split Validation dengan hyperparameter test sebesar 0.2 atau 20\% (untuk hyperparameter train sebesar 0.8 atau 80\%) dan hyperparameter random_state $=42$.

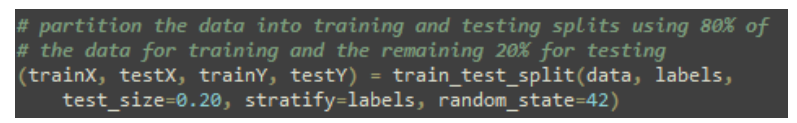

Gambar 6. Validation Model dengan Split Validation

5. Proses Training

Pada langkah selanjutnya adalah melakukan proses training untuk menghasilkan model Machine Learning yang nantinya akan digunakan untuk Face Mask Detection. Hyperparameter tunung pada proses training yang digunakan penulis adalah epochs sebanyak 20 kali dan batch size sebanyak 32 sample.

DOI: 10.52362/jisamar.v5i2.399

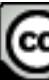

Ciptaan disebarluaskan di bawah Lisensi Creative Commons Atribusi 4.0 Internasional. 
Journal of Information System, Applied, Management, Accounting and Research.

http://journal.stmikjayakarta.ac.id/index.php/jisamar,

jisamar@stmikjayakarta.ac.id, jisamar2017@gmail.com

e-ISSN: 2598-8719 (Online), p-ISSN: 2598-8700 (Printed), Vol. 5 No.2 Mei 2021

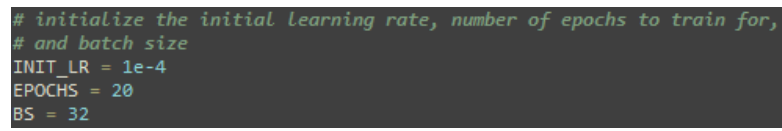

Gambar 7. Hyperparameter tuning untuk proses training

\section{PEMBAHASAN DAN HASIL}

3.1. Perancangan Sistem

Flowchart rancangan pembuatan model Machine Learning yang dibangun dalam penelitian ini ditunjukkan pada Gambar 8 .

DOI: $10.52362 /$ jisamar.v5i2.399

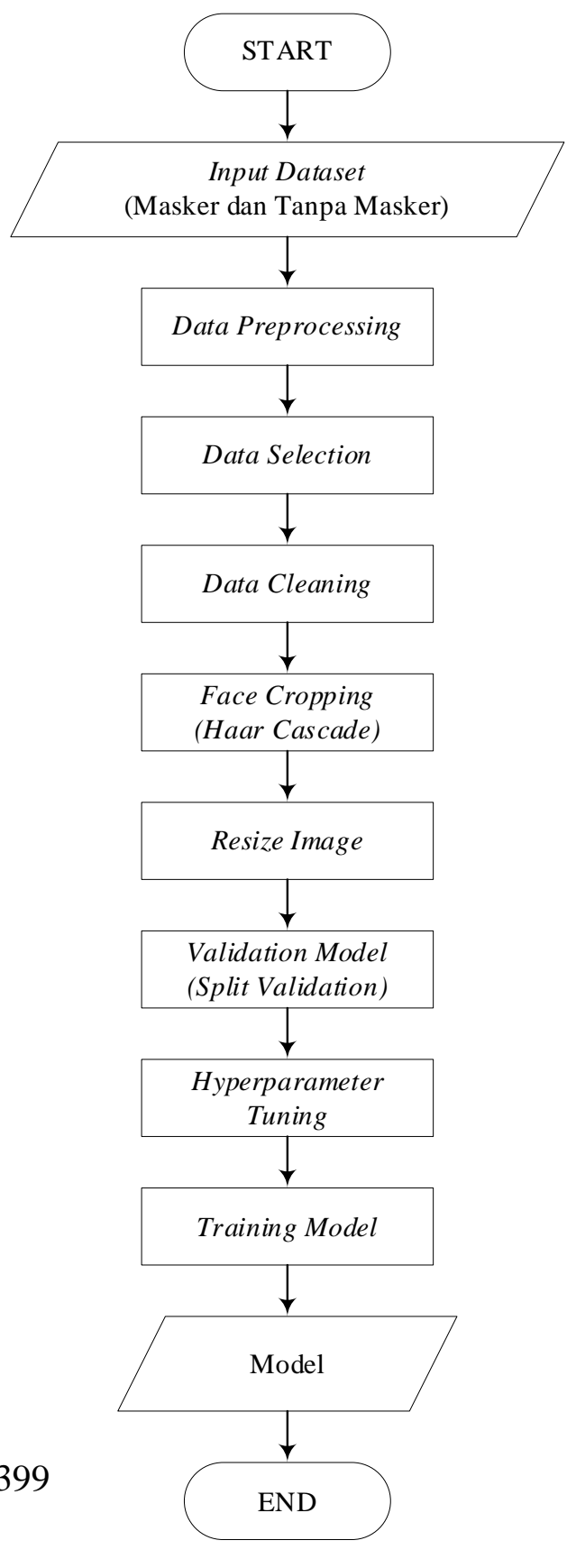

Ciptaan disebarluaskan di bawah Lisensi Creative Commons Atribusi 4.0 Internasional. 
Journal of Information System, Applied, Management, Accounting and Research.

http://journal.stmikjayakarta.ac.id/index.php/jisamar, jisamar@stmikjayakarta.ac.id, jisamar2017@gmail.com

e-ISSN: 2598-8719 (Online), p-ISSN: 2598-8700 (Printed), Vol. 5 No.2 Mei 2021

Gambar 8. Flowchart pembuatan model Machine Learning

\subsection{Evaluasi Model}

Metode evaluasi yang digunakan pada penelitian ini adalah dengan menggunakan Confusion Matrix. Evaluasi ini dilakukan untuk mengetahui seberapa baik model tersebut.

$\begin{array}{rrrrr}\text { [INF0] evaluating network... } & & \\ \text { precision } & \text { recall } & \text { f1-score } & \text { support } \\ \text { Masker } & 0.99 & 0.86 & 0.92 & 383 \\ \text { Tanpa Masker } & 0.88 & 0.99 & 0.93 & 384 \\ & & & & \\ \text { accuracy } & & & 0.93 & 770 \\ \text { macro avg } & 0.93 & 0.93 & 0.93 & 770 \\ \text { weighted avg } & 0.93 & 0.93 & 0.93 & 770\end{array}$

Gambar 9. Evaluasi model menggunakan Confusion Matrix

Untuk mengetahui apakah model tersebut baik yaitu memiliki nilai loss yang rendah dan memiliki nilai accuracy yang tinggi (tidak overfitting dan tidak underfitting), berikut ini grafik hasil dari proses training tersebut.

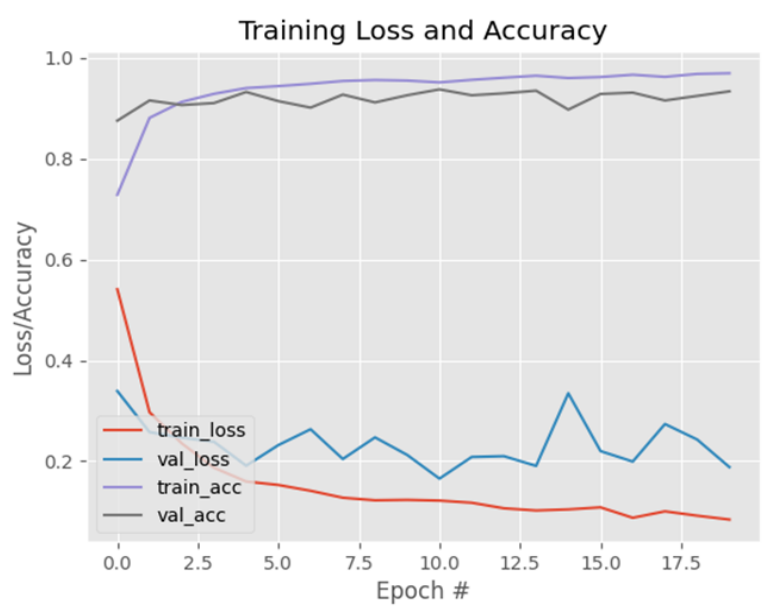

Gambar 10. Grafik Training Loss and Accuracy

Berdasarkan dari Gambar 10, dapat disimpulkan bahwa model tersebut adalah baik karena model ini memiliki nilai nilai loss yang rendah dan memiliki nilai accuracy yang tinggi.

\subsection{Pengujian Sistem}

Pengujian sistem dilakukan untuk mengetahui kinerja sistem yang diimplementasikan. Parameter yang digunakan dalam penelitian ini meliputi :

1. Pengujian di beberapa camera device antara lain dengan menggunakan Webcam Laptop HP True Vision HD (0,92 MP) dan Smartphone Realme 3 (13 MP).

2. Nilai keakuratan pendeteksian disajikan dalam bentuk presentase di masing-masing camera device.

DOI: $10.52362 /$ jisamar.v5i2.399

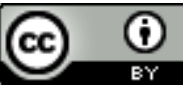

Ciptaan disebarluaskan di bawah Lisensi Creative Commons Atribusi 4.0 Internasional. 


\section{Journal of Information System, Applied, Management, Accounting and Research.}

http://journal.stmikjayakarta.ac.id/index.php/jisamar, jisamar@stmikjayakarta.ac.id , jisamar2017@gmail.com

e-ISSN: 2598-8719 (Online), p-ISSN: 2598-8700 (Printed), Vol. 5 No.2 Mei 2021

3. Posisi sudut wajah memakai masker dan tanpa memakai masker dalam pendeteksian di masing-masing camera device.

Tabel 1. Pengujian Pendeteksian Masker Berdasarkan Posisi Face Image dengan Perbandingan 2 Camera Device

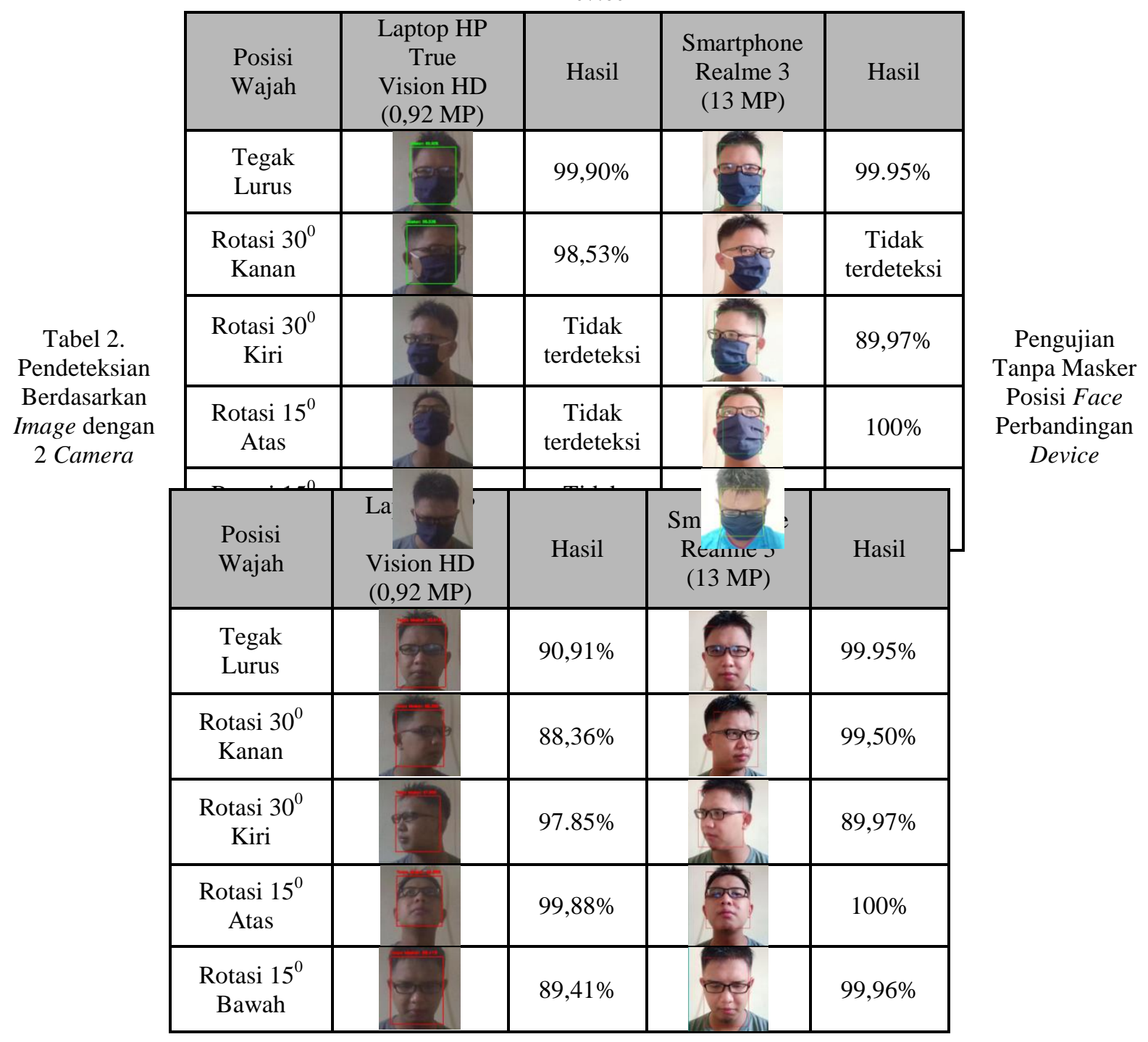

\section{KESIMPULAN}

Face Mask Detection berbasis Machine Learning dapat berjalan dengan baik, dimana mampu untuk mendeteksi wajah memakai masker dan wajah tanpa memakai masker. Untuk Face Mask Detection yang optimal, perlu memperhatikan faktor krusial dalam proses pendeteksian. Antara lain kualitas pengambilan gambar, kemiringan sudut posisi wajah, dan intensitas cahaya.

\section{REFERENSI}

DOI: 10.52362/jisamar.v5i2.399

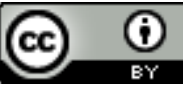

Ciptaan disebarluaskan di bawah Lisensi Creative Commons Atribusi 4.0 Internasional. 
Journal of Information System, Applied, Management, Accounting and Research.

http://journal.stmikjayakarta.ac.id/index.php/jisamar, jisamar@stmikjayakarta.ac.id, jisamar2017@gmail.com

e-ISSN: 2598-8719 (Online), p-ISSN: 2598-8700 (Printed), Vol. 5 No.2 Mei 2021

[1] R. Sebayang, “Awas! WHO Akhirnya Tetapkan Corona Darurat Global,”www.cnbcindonesia.com, 2020. [Online]. Tersedia pada: https://www.cnbcindonesia.com/news/20200131060856-4-134146/awas-whoakhirnya-tetapkan-corona-darurat-global. [Diakses: 14-Okt-2020].

[2] N. Nurhalimah, "UPAYA BELA NEGARA MELALUI SOSIAL DISTANCING DAN LOCKDOWN UNTUK MENGATASI WABAH COVID-19 (Efforts to Defend the Country Through Social Distancing and Lockdown to Overcome the COVID-19 plague)," SSRN Electron. J., vol. 19, 2020.

[3] Wandi, "Kecamatan Kemayoran Gelar Razia Masker Malam Hari - Poskota News," 12 Mei $2020,2020$. [Online]. Tersedia pada: https://poskota.co.id/2020/5/12/kecamatan-kemayoran-gelar-razia-masker-malam-hari. [Diakses: 28-Okt-2020].

[4] W. Marison, “Jalankan Operasi Yustisi, Pemkot Jaktim Mengaku Kekurangan Personel Satpol PP,” 23 September 2020, 2020. [Online]. Tersedia https://megapolitan.kompas.com/read/2020/09/23/12453361/jalankan-operasi-yustisi-pemkot-jaktim-mengakukekurangan-personel-satpol. [Diakses: 27-Okt-2020].

[5] Z. Wang $d k k$., "Masked face recognition dataset and application," arXiv. 2020.

DOI: $10.52362 /$ jisamar.v5i2.399 


\title{
SURAT PERNYATAAN KEASLIAN NASKAH \\ (Statement of Authenticity of Status)
}

Yang bertanda tangan di bawah ini menyatakan bahwa:

Judul naskah:

\section{"IMPLEMENTASI FACE MASK DETECTION UNTUK MENGHAMBAT LAJU PENYEBARAN COVID-19 BERBASIS MACHINE LEARNING"}

Penulis:

1. Nama : Reza Marwansyah

2. Nama : Astriana Mulyani

\author{
e-mail : rezakatsuhiko@gmail.com \\ e-mail : astriana.atm@nusamandiri.ac.id
}

Nama dan alamat penulis 1 (perwakilan) untuk korespondensi:

Nama : Reza Marwansyah

Alamat: Universitas Nusa Mandiri, Jalan Kramat Raya No. 18, Senen, Jakarta Pusat

Telp. : 085694011850

e-mail : rezakatsuhiko@gmail.com

- Jurnal/Artikel tersebut di atas merupakan naskah asli, hasil karya penulis, dan bukan merupakanplagiat dari artikel atau karya ilmiah orang lain.

- Jurnal/Artikel tersebut di atas belum pernah dipublikasikan atau tidak sedang diajukan untukdimuat pada jurnal atau media lainnya.

- Apabila kemudian hari pernyataan ini tidak benar, maka penulis bersedia menerima sanksi dengan peraturan perundang-undangan yang berlaku.

Jakarta, 3 Mei 2021

Penulis 1,

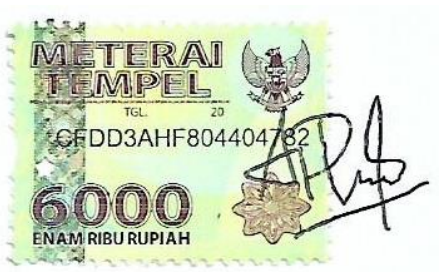

Reza Marwansyah
Penulis 2,

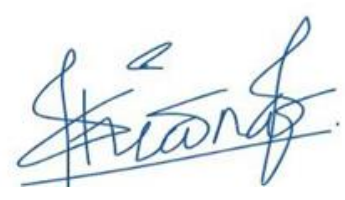

Astriana Mulyani 


\section{SURAT PERNYATAAN KESEDIAAN PUBLIKASI \\ (Statement of Publication Availability)}

Saya yang bertandatangan di bawahini :

Nama (Penulis 1) : Reza Marwansyah

Asal Institusi : : Universitas Nusa Mandiri

No.Telepon : 085694011850

Email $\quad$ : rezakatsuhiko@gmail.com

Bersama ini saya menyatakan BERSEDIA/THPAK BERSEDIA*) untuk publikasi paper dengan judul :

\section{“IMPLEMENTASI FACE MASK DETECTION UNTUK MENGHAMBAT LAJU PENYEBARAN COVID-19 BERBASIS MACHINE LEARNING"}

Di JISAMAR (Journal of Information System, Applied, Management, Accounting and Research) : Vol 5, No 2, Tahun 2021.

Saya menyatakan bahwa karya ilmiah tersebut di atas terbebas dari unsure plagiarism dan publikasi ganda (belum pernah dipublikasikan ke media manapun).Serta tidak akan diterbitkan ulang padaJ urnal/Buku dan atau majalah lainnya.

Saya juga bersedia membayar biaya publikasi pada JISAMAR (Journal of Information System, Applied, Management, Accounting and Research) sesuai ketentuan dan aturan yang berlaku**).

Demikian surat pernyataan ini dibuat dalam keadaan sehatwal'afiat tanpa paksaan dari pihak manapun dan agar dapat dipergunakan sebagaimana mestinya.

Jakarta, 3 Mei 2021

Yang Membuat Pernyataan

Penulis 1,

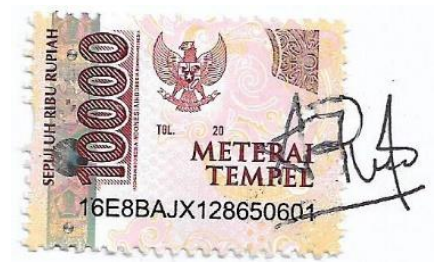

(Reza Marwansyah)
Penulis 2,

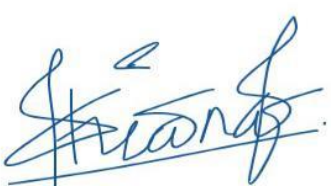

(Astriana Mulyani)

Note :

* :Coret yang tidak sesuai(disesuaikan)

** :Dibayar setelah artikel dinyatakan SIAP PUBLISH. Biaya publikasi bisa dilihat di web JISAMAR 